\title{
The US-Taliban Agreement
}

\author{
Abdul Qayum Mohmand*
}

The United States was eager to negotiate with the Taliban, bring a 19-year war to an end, and leave Afghanistan sooner rather than later. Analysing the published version of the peace agreement, however, it is very uncertain that it will lead to a stable and lasting peace in Afghanistan. For a peace agreement and a peace process to be successful, both need to be comprehensive and include the different stakeholders involved in the conflict. Presumably, the United States has hoped that the signing of an agreement with the Taliban will set the stage for future peace talks between the various players in Afghanistan itself so that the civil war there will come to an end.

Even though the current peace agreement will not bring peace to Afghanistan, it is a new start that will provide leverage to the three sides in the war, namely the United States, the Afghan Government, and the Taliban. Even though the Afghan Government was excluded from the initial peace negotiations in Qatar, the outcome of the latter may turn out to be advantageous for them. The language of the agreement provides a wide range of options to the Afghan Government, enabling them to define and select who shall participate in intra-Afghan dialogue and co-determine the future look and form of Afghan political constructs.

Part One of the agreement elaborates on "Guarantees and enforcement mechanisms that will prevent the use of the soil of Afghanistan by any group or individuals against the security of the United States and its allies." This point is re-emphasised in Part Three of the agreement, with slight changes in the language, namely, "Afghan soil will not be used against the security of the United States and its allies." By agreeing to these terms and the language of the agreement, the Taliban have admitted that the soil of Afghanistan under their regime (19962001) was used by groups and individuals operating against the security of the United States and its allies. This is an extraordinary admission by the Taliban, which has claimed in the past that there were no such groups in Afghanistan.

In agreeing to terms in Part Two, Sections 1-5 of the agreement, the Taliban have likewise admitted that under their regime individuals and groups, including al-Qaeda, were allowed to use Afghanistan to threaten the security of the United States and its allies. By agreeing that "the Taliban will send a clear message that those who pose a threat to the security of the United States and its allies have no place in Afghanistan, and will instruct members of the Taliban not to cooperate with groups or individuals threatening the security of the United States and its 
allies," the Taliban have affirmed the United States and international community's assertion that the Taliban were cooperating with these individuals and groups, which they have always denied. The Taliban have also admitted that under their regime groups and terrorists were recruited, trained, and funded, which they "will prevent... and will not host" in the future.

The agreement also places restrictions on the Taliban's ability to award asylum or residency to persons who "pose a threat to the security of the United States and its allies," and requires the Taliban not to "provide visas, passports, travel permits, or other legal documents to those who pose a threat to the security of the United States and its allies to enter Afghanistan." Once again, by agreeing to these terms, the Taliban have admitted that in the past they allowed elements to reside in Afghanistan and operate against the interests of the United States and its allies.

Part Two of the agreement "Guarantees, enforcement mechanisms, and announcement of a timeline for the withdrawal of all foreign forces from Afghanistan." That this is included in an agreement with the Taliban and not the Government of Afghanistan confirms the Taliban's claim that Afghanistan was invaded, its territorial integrity violated, and the United States, NATO, and other international forces were occupying forces. That the United States commits to withdrawing its forces, that of its allies and coalition partners, "including all nondiplomatic civilian personnel, private security contractors, trainers, advisors and supporting service personnel within fourteen months following announcement of this agreement" also legitimises the Taliban's war against the United States and international forces as a war of liberation.

Part Three, Section 1 of the agreement states that "the United States will request the recognition and endorsement of the United Nations Security Council for this agreement." This officially endorses the Taliban as a legitimate resistance group, annulling their status as a terrorist organisation. It gives the Taliban international recognition and prestige; certainly many countries were eager to meet with the Taliban delegation in Qatar.

Part Three of the agreement states that "the Taliban will start intra-Afghan negotiations with Afghan sides on March 10, 2020." The term "intra-Afghan" is not clearly defined, making it uncertain who shall be included in these "intraAfghan negotiations" and who shall make the decision about the construction of an intra-Afghan dialogue. The Taliban have stated in the past, for example, that they do not recognise the Government of Afghanistan as a legitimate body with which they will work. By leaving the language of this passage vague, however, the Afghan American diplomat Zalmay Khalilzad has masterfully included a future path for the Government of Afghanistan to enter as a negotiating partner. In practice, as we are witnessing, there are indeed only two parties meeting in 
Doha: the Taliban and the Government of Afghanistan. Whether the Taliban deny it or accept it, they are negotiating with the Government of Afghanistan. Even though the latter was not present during the negotiations or at the signing of the agreement, it still comes out as an important player and negotiating partner by being able to co-determine the construction of intra-Afghan dialogue and the future direction of the peace negotiations.

In Part Three, the agreement states that "the United States and the Taliban seek positive relations with each other and expect that the relations between the United States and the new post-settlement Afghan Islamic government as determined by the intra-Afghan dialogue and negotiations will be positive." Aside from the ceasefire, "Afghan Islamic government" is the main point of contention and disagreement here. The Afghan Government considers the current structure and form of government in the country to be already Islamic and wants to keep the status quo. It also claims to have accumulated numerous achievements over the past 19 years, which it wants to maintain. The Taliban, on the other hand, wants to create an Islamic government based on their own understanding and interpretation of Islam. Two examples stand out, which indicate how far apart the thinking of the two sides are in this matter. First, it became a matter of contentious disagreement whether an issue on which there was no consensus should be referred to Hanafi figh alone or both Hanafi fiqh and Jafari fiqh. This issue was resolved after weeks of negotiation, when comments were made in the discussions that the current Afghan constitution refers matters of disagreement to Hanafi fiqh as a last resort. Second, the Taliban insisted that the US-Taliban Agreement be the basis for any intra-Afghan negotiations, whereas the Afghan Government argued that the negotiations should be based on the Qur'an and Sunnah. After weeks of back and forth, the Afghan Government agreed to accept the US-Taliban Agreement as the basis of negotiations.

The future structure of an Afghan Islamic government remains an issue of conflict and disagreement. The Taliban have said in interviews that they will not accept a republican form of government, wanting instead to create a government based on Islamic principles and shariah. The Afghan Government insists that the current form of government is already Islamic. These differences will continue and will create major points of contention between the two sides, possibly even derailing the negotiations once again.

Part Four of the agreement further strengthens the position of the Afghan Government: "A permanent and comprehensive ceasefire will be an item on the agenda of the intra-Afghan dialogue and negotiations. The participants of intraAfghan negotiations will discuss the date and modalities of a permanent and comprehensive ceasefire, including joint implementation mechanisms, which will be announced along with the completion and agreement over the future 
political roadmap of Afghanistan." Since the ceasefire can only be realised and implemented by the warring parties - that is, the Taliban and the Government of Afghanistan - all parties are agreeing that the Government of Afghanistan is a negotiating partner, despite the long-held Taliban claim that it is not a legitimate government.

\section{Notes}

* Abdul Qayum Mohmand is an Independent Researcher and Consultant. He was previously a Department Chair and Assistant Professor. He can be contacted at: heywad@hotmail.com. 